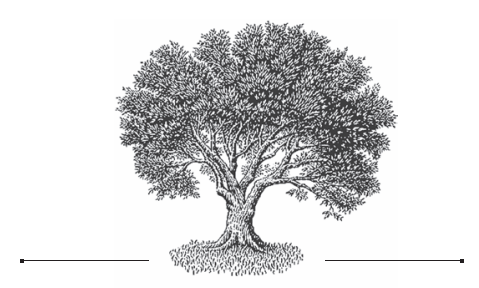

\section{Женский постриг}

и женское

монашество

в Аревней Руси и на Балканах

\section{Татьяна Игоревна \\ Афанасьева}

С.-Петербургский государственный университет

С.-Петербург, Россия

\section{Таисия Дебер}

Майнцский университет им. Иоганна Гутенберга

Майнц, Германия

\section{The Female Tonsure and Female Monasticism in Old Russia and the Balkans}

\author{
Tatiana I. Afanasyeva
}

St. Petersburg State University

St. Petersburg, Russia

\section{Taisiya Leber}

Johannes Gutenberg-Universität Mainz Mainz, Germany

\title{
Резюме
}

В статье описывается редкий чин женского пострига, известный по нескольким славянским требникам XIII-XVI вв., и делается попытка на основании исторических источников выяснить, как мог осуществдяться этот постриг на Балканах и в Древней Руси. Н. Ф. Красносельцев предположил, что этот постриг был весьма древнего происхождения и был предназначен

* Статья написана при финансовой поддержке РФФИ № 18-512-18006.

Цитирование: Афанасьева Т. И., Аебер Т. Женский постриг и женское монашество в Древней Руси и на Балканах // Slověne. 2020. Vol. 9, № 1. С. 81-109.

Citation: Afanasyeva T. I., Leber T. (2020) The Female Tonsure and Female Monasticism in Old Russia and the Balkans. Slověne, Vol. 9, № 1, p. 81-109.

DOI: $10.31168 / 2305-6754.2020 .9 .1 .3$ 
для пострижения дев, дававших обет безбрачия. Греческий оригинал данного последования известен только в одном евхологии Coisl.213 1027 г. Сохранившийся славянский перевод, по мнению авторов, был сделан не ранее XIII в. и имел сербское происхождение, но в дальнейшем на Балканах, по-видимому, не использовался. На Руси он имел скудную рукописную традицию: с XIV в. чинопоследование сокращадось и попададо под вдияние более поздней практики пострига. Тем не менее данные исторических источников показывают, что пострижение дев было весьма частым явлением именно в Киевской Руси, где существовали городские женские монастыри, в то время как в средневековой Болгарии и Сербии быди распространены случаи, когда вдовы принимали монашеский постриг, не вступая в монастырь. Трудно сказать, существовали ди там вообще развитые женские монашеские общины до конца XIV в. в том виде, в каком они известны на Руси. В статье делается предположение о том, что постриг дев имел место именно в Древней Руси по чину, весьма близкому к списку Гильф. 21: в нем, скорее всего, отсутствовала конечная часть - модитва на снятие куколя, как в Coisl. 213.

Ключевые слова

женский постриг, история женского монашества, требники, жития святых

Abstract

This paper describes a rare rite of female tonsure that is known from five Slavonic Euchologia (Trebnik) of the 13th-16th centuries and attempts to investigate on the basis of historical sources how this rite of tonsure could be applied in the Balkans and in Early Russia. N. F. Krasnosel'tsev suggested that this tonsure was of a very ancient origin and was intended for tonsuring virgins who took the vow of celibacy. The Greek original of this rite is preserved only in one known Euchologion Coisl.213 (1027). We argue that its Slavonic translation is of a Serbian origin and was made not earlier than in the 13th century, but that it apparently was not used in the Balkans afterwards. In Early Russia this rite is scantily attested in written sources - since the 14th century its content was shortened and influenced by the later practice of tonsure. However, historical sources prove that tonsuring of virgins was very common in Kievan Rus' with its urban convents, while it was practically unknown in the Balkans. In medieval Bulgaria and Serbia there were recorded cases of widows tonsured without entering the monastery. It is difficult to say whether before the end of 14th century any fully developed female monastic communities existed in this region in the form in which they are known in Rus'. Probably, the rite of tonsure of virgins in Old Russia was very close to the rite from the manuscript Gilf.21, though, most likely, it did not contain the final part - the prayer for the removal of the veil (kukol'), as in Coisl.213.

Keywords

female tonsure, history of female monasticism, Euchologia, vitae of female saints 
1. Особый чин женского пострига и его славянские списки

В греческих и славянских требниках сохранилось свидетельство о том, что в Средневековье существовал особый чин женского пострига, принципиально отличавшийся от мужского. Он содержал чин умовения ног, а также специальные песнопения, приспособленные именно к женскому пострижению. Их особенность заключалась в том, что здесь подчеркивался статус монахинь как невест Христовых, а самого пострига как небесного брака. Впервые об этом в 1889 г. написал Н. Ф. Красносельцев: он опубликовал текст чинопоследования женского пострига по русской рукописи XVI в. из собрания Соловецкой библиотеки Сoлов.1086/1195 с разночтениями по сокращенному последованию из рукописи той же библиотеки - Солов.1085/1194. При этом Красносельцев указал, что этот чин гораздо старше XVI в., это отголосок того времени, когда в древней христианской церкви было учреждено служение дев, дававших обет безбрачия - virgines consecratae. Обряд посвящения в церковные девы был торжественным, 6-е правило Карфагенского собоpa 419 г. предписывает совершать его только епископам [Красносельцев 1889: 134-169]. Греческие параллели славянскому чину женского пострига Красносельцеву остались неизвестными.

Статья Н. Ф. Красносельцева в этом же году была подвергнута обстоятельной критике его учеником А. А. Дмитриевским. Он написал о том, что в греческих евхологиях не имеется подобного последования, но Н. Ф. Красносельцев не хочет примириться с данным фактом и идет на поводу у своего непреодолимого желания увидеть в славянских рукописях отражение некоего древнего греческого чина. Дмитриевский указал на рукопись Афонского Кутлумушского монастыря № 491 (XIV в.) евхологий, специально составленный для константинопольского женского монастыря Спаса Филантропа. В нем почти все чины изложены в применении для женского монастыря, в том числе и чин елеоосвящения

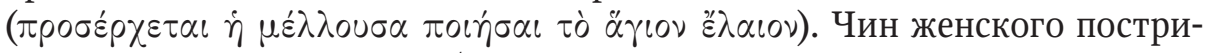
жения изложен здесь по образцу чина мужского - с незначительными особенностями, о которых в самом памятнике замечается, что они были

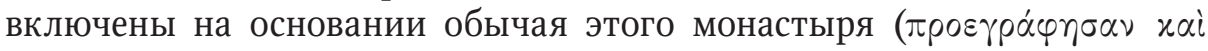

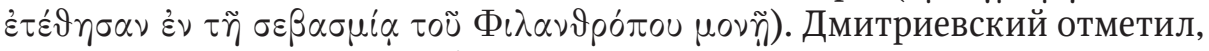
что в данном евхологии «было весьма уместно поместить чин женского пострижения в той редакции, которая известна Красносельцеву, но и здесь мы ее не находим. Это обстоятельство дает основание думать, что настоящего чина женского пострижения вовсе не было известно в практике греческой церкви» [Дмитриевский 1889: 443-445].

В 1896 г., после работы с греческими евхологиями в Парижской национальной библиотеке и обнаружения рукописи Coisl.213 (1027 г.), в 
которой чин женского пострига близок русскому списку Солов.1086/1195, Дмитриевский изменил свое мнение. Он полностью опубликовал чин женского пострига по этой рукописи во II томе «Описаний литургических рукописей», однако никак не прокомментировал его историю [Дмитриевский 1901: 1035-1041]. Таким образом в начале XI в. в Константинополе древний чин пострига в церковные девы был возрожден, отредактирован и, видимо, использовался в монастырях византийской столицы. В настоящей работе мы попытаемся указать на особенности этого текста в славянской традиции и рассмотрим исторические свидетельства о постриге дев у православных славян.

А. А. Дмитриевский в рецензии на статью Красносельцева указал, что этот чин был употребляем в Сербии, и впервые упомянул сербский требник Гильф.21 XIII-XIV в. [Дмитриевский 1889: 445]. Н. Н. Пальмов [1914: XIV] указал еще один славянский список женского пострига - требник XIV в. из собрания Троице-Сергиевой лавры TCЛ.229. В процессе нашей работы были найдены еще два русских списка этого пострига 2-й половины XV в. (Олон.34 и Арханг.1193 - с утратами в начале текста), которые полностью идентичны опубликованному Красносельцевым Солов.1086/1195. Обнаружен еще один список, близкий к краткой редакции пострига в требнике Солов.1085/1194, - Eдuн.78. Предположения Н. Ф. Красносельцева оказались верными: эта служба существовала на Руси ранее XVI в., поскольку стал известен русский список XIV в. Тем не менее вопрос о времени славянского перевода данного чина остается открытым.

Рукопись Гильф.21, как показало наше исследование, является конечной частью Большого требника и содержит новые переводы, выполненные в начале XIII в., в ходе восстановления славянской письменности после византийского завоевания Первого болгарского царства. Богослужебные переводы этого времени делались на Афоне в кругу книжников Саввы Сербского. Святителю приписывается создание Кормчей книги, так называемой Сербской кормчей [Щапов 1978: 117158], создание особой разновидности служебного Евангелия - нового литургического тетра [Алексеев 1999: 173]. Известно, что литургические реформы св. Саввы Сербского опирались на Евергетидский типикон, и Хиландарский типик св. Саввы сделан на его основе [Дмитриевский 1895: XLIV-LII]. Видимо, в этом же кругу создавался и новый перевод Евхология, который мы условно назвали Евхологием Саввы Сербского [Афанасьева 2019: 144-156].

В Константинополе было несколько монастырей, устав которых зависел от Евергетидского типикона, а именно - Христа Филантропа и св. Маманта, а также женский монастырь Богородицы Благодатной 


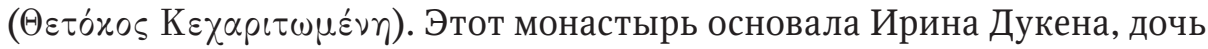
Андроника Дуки и жена Алексея Комнина: она дала ему устав, сохранившийся в рукописи Paris.gr.384, отрывок из которого читается в иерусалимской рукописи $S$. Crusis57. Составление его датируется временным промежутком 1096-1118 гг. Изучение и публикация этого устава были предприняты П. Готье [Gautier 1985]. В этом тексте, к сожалению, ничего не сказано о том, как происходит женский постриг, упоминается лишь о том, что игуменья совершает умовение ног в притворе храма (глава 72), однако в каких случаях оно совершается, не указано.

Предположение о том, что сербский список женского пострига Гильф.21 отражает практику монастыря Богородицы Благодатной, пока остается без серьезных доказательств, мы можем высказать лишь ряд предположений. Гипотеза базируется на информации о том, что монастырь Богородицы Благодатной опирался на Евергетидский типикон, который был также основой для богослужебного устава монастырей, созданных св. Саввой Сербским. Поэтому он мог использоваться и для женских монастырей Сербии. Евергетидский типикон во многих пунктах следовал уставу Великой церкви и перенял оттуда некоторые традиции, например, в нем после обычного чина Великой церкви - чина умовения ног в Великий четверг - помещены молитвы святого умо-

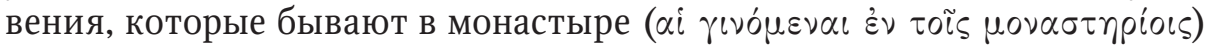
[Дмитриевский 1895: 549], т. е. этот кафедральный обряд представлен в монастырском варианте. Умовение ног было и в Студийском монастыре, оно тоже происходило в притворе храма; видимо, эту практику перенимали многие столичные монастыри.

Сравнение трех славянских списков с греческим оригиналом XI в. показало, что ближе всего к греческому тексту оказывается рукопись Гильф.21. В ней до мельчайших подробностей переданы особенности Coisl.213, более того, она позволяет восстановить лакуну в Coisl.213 в начале службы. Установление такого близкого греческого соответствия славянскому переводу - редкая удача при изучении славянского богослужения, т. к. большинство славянских последований имеет серьезные отличия от тех греческих оригиналов, которые сохранились до наших дней и введены в научный оборот.

Женский постриг начинался после отпуста утрени: за ним были записаны седальны, после их окончания была помещена рубрика о том, что игуменья берет за руку девушку, которая собирается принять постриг, и ведет ее в церковный притвор. Здесь уже все подготовлено для умовения ног. Все сестры идут туда со свечами и поют стихиру Bьск

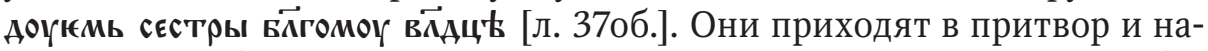
чинают службу умовения ног, отличавшуюся от кафедральной службы. 
Она состояла из трех антифонов, после которых произносилась ектения и молитва Гй прқвй гын·нєпрнстоупнын вж(с) твомь [л. 380б.]. На этой молитве заканчивается лакуна в Coisl.213. Далее следует главо-

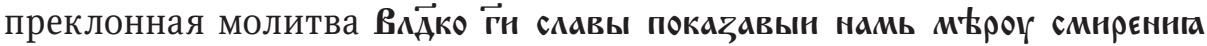
[л. 39]. Отметим, что именно эти две молитвы предписывается читать в монастырском чине умовения ног в Евергетидском типиконе [Дмитриевский 1895: 549], в Студийско-Алексеевском уставе они не отмечены [Пентковский 2001: 251-252].

Затем читаются две перикопы из Евангелия от Иоанна и следует само умовение, которое совершает игуменья. Поются стихира Оүмын

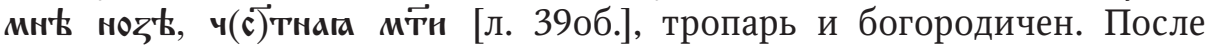
окончания обряда сестры умывают лица водой, которой происходило умовение ног. На эту же практику указывает и славянская версия константинопольского кафедрального чина умовения ног в Великий четверг, однако о ней умалчивает Студийско-Алексеевский устав, распространенный на Руси в XI-XIV вв. B Coisl.213 в этом месте находится лакуна, но ее можно восстановить по переводу эпохи митрополита Киприана, сохранившемуся в некоторых славянских рукописях [Афанасьева et al. 2019: 232].

Далее все возвращаются из притвора в церковь и поют тропари пятой песни канона Великой пятницы. Они полностью записаны в Гильф.21, но отсутствуют в Coisl.213, где для них было оставлено место. Затем начинается литургия, на которой поют особые антифоны, предназначенные именно для женского пострига: здесь основную тему составляет обручение с небесным женихом и ожидание его с горящим светильником:

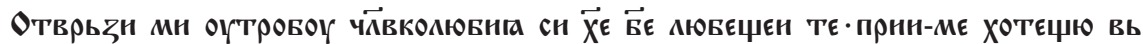

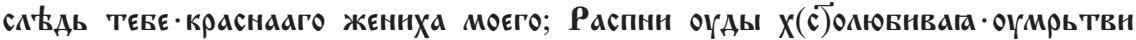

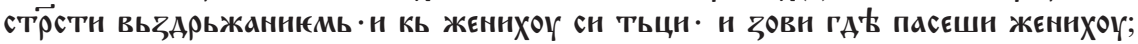

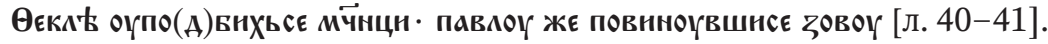

Упоминание Феклы, спутницы апостола Павла, ради которого она бросила отчий дом, несколько раз встречается в песнопениях женского пострига. Содержание песнопений было подробно рассмотрено Н. Ф. Красносельцевым: он указал, что данное последование отражает древнюю традицию постригов в церковные девы, ее отголоски мы встречаем у древних авторов и в деяниях Вселенских соборов.

По окончании пения антифонов священник задает вопросы постригающейся, но в обеих рукописях (и в Coisl.213, и в Гильф.21) они не выписаны; как указано в рукописях, они такие же, как в мужском постриге. Далее следует острижение волос, которое предписано совершать 
сестрам в дьяконнике, а затем они ведут постригающуюся в простой сорочке ко входу в церковь. После чтения Евангелия поются особые антифоны, предназначенные для женского пострига. Во время их пения постригающаяся доходит до амвона, потом встает перед святыми вратами, и священник, взяв ее за руку, вводит в алтарь. В этот момент поется стихира о том, что открывается небесный чертог и заключается небесный брак.

В алтаре происходит одевание новопостриженной, после чего священник читает молитвы, не записанные в обеих рукописях (тоже дается отсылка к мужскому пострижению). В это время поются стихиры «женам», в которых красной нитью проходит тема небесного брака. Потом новопостриженная целует святое Евангелие, которое держит дьякон вне святых дверей, а за ней целуют его игуменья и сестры. Во время целования поются стихиры о встрече небесного жениха.

После окончания литургии монахини вместе с новопостриженной идут в трапезную и поют стихиры. После трапезы все возвращаются в церковь и по дороге поют азбучные стихиры Андрея Критского, также предназначенные для женского пострига. В рукописи Coisl.213 отмечены киноварью инципиты каждой четвертой стихиры, т. е. выделено начало четерехстрочного тропаря, а три другие его строки не обозначены. В современном гимнографическом справочнике С. Евстратиадиса, к сожалению, приведены только первые строки тропаря, а остальные стихи не указаны, поэтому азбучный акростих не виден [Eustratiades 1935: 462]. Единственный греческий список, содержащий азбучные стихиры Андрея Критского на постриг монахини, передан в нем не полностью. Представим эти азбучные стихиры на следующей схеме:

\begin{tabular}{|c|c|c|c|c|c|}
\hline $\mathrm{A}$ & $\mathrm{E}$ & $\mathrm{I}$ & $\mathrm{N}$ & $\mathrm{P}$ & $\Phi$ \\
\hline$\beta$ & $\zeta$ & $\chi$ & $\xi$ & $\sigma$ & $\chi$ \\
\hline$\gamma$ & $\eta$ & $\lambda$ & 0 & $\tau$ & $\psi$ \\
\hline$\delta$ & $\vartheta$ & $\mu$ & $\pi$ & 0 & $\omega$ \\
\hline
\end{tabular}

В конце каждого тропаря, т. е. в строках, начинающихся с $\delta, \vartheta, \mu, \pi$, u и (), дан возглас, служащий своеобразным припевом к тропарю в целом,

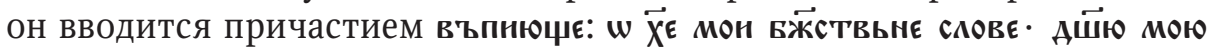

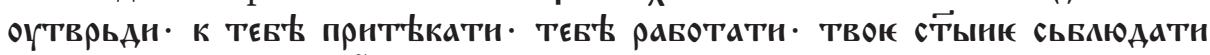

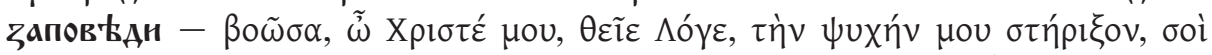

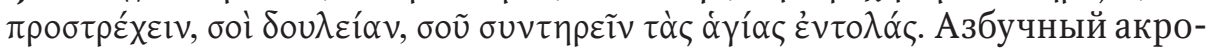
стих в славянском переводе, к сожалению, не передается.

После окончания трапезы поются другие стихиры на тот же глас, где также основная тема - небесный брак. Потом все встают, игуменья 
ведет новопостриженную в церковь, и все поют стихиру $\overrightarrow{\boldsymbol{\Gamma}} \overrightarrow{\boldsymbol{\Gamma}} \boldsymbol{\mathbf { n }}$ прнцрн с нг् се [л. 47об]. На этом греческое последование заканчивается.

В славянском чине добавляется рубрика о пребывании новопостриженной в церкви 7 дней без всякого дела, а на 8-й день священник читает над ней молитву на снятие куколя, как и в мужском постриге. Отсылка к мужскому постригу в Гильф.21 свидетельствует, что предполагалось чтение молитвы Многомйстнве гй даровавын равоу твоюмоу сємоу [л. 36об.]. Данная молитва не соответствует молитве єгда снати когкоциь в мужском постриге из Синайского глаголического евхология XI в.; в последнем читается совсем другая молитва, неизвестная в греческих списках и находящаяся еще в одном славянском требнике РНБ, Греч.70 [л. 8об.], также происходящем с Синая. По-видимому, добавление молитвы на снятие куколя в славянском переводе женского пострига - это нововведение по сравнению с Coisl.213. Сильное влияние чина мужского пострига на женский приводило к тому, что последний постепенно восполнялся молитвами и литургическими действиями из мужского. Это хорошо видно по отсылкам из женского пострига к мужскому (вопросы священника постригаемой) в Coisl.213, и по Гuльф.21, где таких отсылок гораздо больше, чем в греческом евхологии. Видимо, на рубеже X-XI вв., когда составлялась рукопись Coisl.213, в чине женского пострига молитвы на снятие куколя еще не было. Таким образом, славянское последование восходит к более поздней греческой традиции, когда формируется конечная часть женского пострига: действия и молитвы на 8 день после принятия женщиной монашеского обета. Именно с такого более позднего последования и был сделан славянский перевод. Учитывая, что монастырь Богородицы Благодатной и его богослужебная практика формировалась в XI-XII вв., влияние мужского пострига, как нам представляется, здесь проявлялось в большей степени. После захвата Константинополя в 1204 г. традиция особого пострига в монахини в Константинополе, видимо, была утрачена. При восстановлении богослужения в палеологовское время женские постриги стали совершаться так же, как и мужские, о чем свидетельствует евхологий XIV в. константинопольского женского монастыря Спаса Филантропа.

Итак, исследуемый чин женского пострижения, на наш взгляд, восходит к константинопольскому богослужению до латинского завоевания. Его славянский перевод мог быть сделан у южных славян в начале XIII в., в эпоху восстановления славянской письменности и богослужения после византийского завоевания Первого Болгарского царства. На Русь этот текст мог попасть в конце XIII в. вместе с другими богослужебными и каноническим книгами - с Сербской кормчей и новым литургическим тетром. Однако этот чин употреблялся редко, 
его следующий список ТСЛ.229 начала XV в. по сравнению с Гильф.21 сильно сокращен: здесь совпадает только первая часть службы, умовение ног и пение антифонов.

После реформ митрополита Киприана в конце XIV в. постриги мужчин и женщин перестали отличаться друг от друга. Об этом свидетельствуют ответы митрополита Киприана игумену Афанасию, где постулируется, что постриги мужчин и женщин одинаковы: «пострижение чернецам и черницам едино есть, но токмо молитвы, егда прочитаеть постригалныя, и приидет ижеде имена святых и преподобных отец написана суть, тогда пременяеть имена на преподобных святых жен» [РИБ 1880: 256].

На рубеже XV-XVI в. на Руси делается попытка возродить особые чины женского пострига, она отражена в четырех русских рукописях: двух, содержащих полное последование - Солов.1086/1195, Олон.34, и двух с сокращенным последованием - Арханг.1193 и Сол.1085/1194. Полное последование наиболее близко к Гильф.21. По публикации Красносельцева мы можем видеть, что в требнике Солов.1086/1195 есть вопросы женщине, принимающей постриг, и длинное поучение священника: Блюан сестро, каковага ов Бтованига даєшн... Данного текста нет в старших списках Гильф.21 и ТСЛ.229. Как показало наше сравнение различных редакций постригов, данный текст - это заимствование из более поздней редакции мужского пострига, которая появляется в конце XIV в. и зафиксирована в сербской рукописи Q.n.I.61. Однако в русской рукописи это увещевание приспособлено к постригу монахини: вместо «брате» везде поставлено «сестро».

В требнике Солов.1086/1195 по-другому описано пострижение, и это описание отредактировано под влиянием более поздней практики, пришедшей на Русь в конце XIV в. Здесь вставлена молитва Прєщєдрын

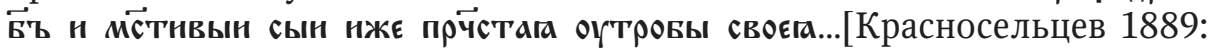
159], которой нет в Гильф.21, но эта молитва есть в Афонской редакции великого пострига, и перевод в Солов.1086/1195 полностью совпадает с рукописью Q.n.I.61. Ножницы для подстригания подаются священнику на евангелии, в Гильф.21 такой рубрики нет. Далее следует молитва

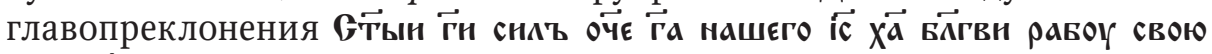
сію нМ̈рк ЮЖе нбБра Аєсннца твога [Ibid.: 161], которая в ГИЛьф.21 отсутствует. Нет сомнения в том, что в Солов.1086/1195 вставлен целый блок из более поздней Афонской редакции: поучение к постригающейся, молитва за нее и молитва главопреклонения. Подобным образом в последование вставлены молитвы в Афонском переводе, читающиеся в конце

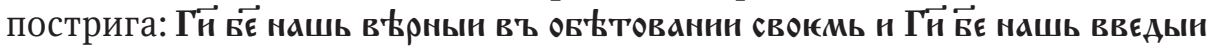

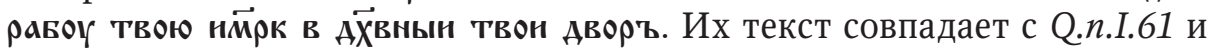


отличается от редакции этих же молитв в мужском постриге Гильф.21. Кроме того, азбучные стихиры Андрея Критского в Солов.1086/1195 не упоминают его как автора, авторство сохраняется только в Гильф.21. При этом в Солов.1086/1195 имеется последний тропарь из четырех азбучных строк, который в Гильф.21 пропущен по непонятным причинам. Строфа восстанавливается только по поздним спискам: Храннтнса

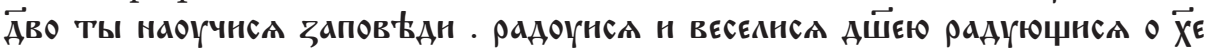

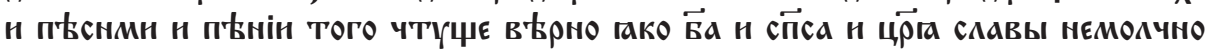

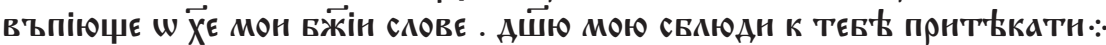

Все приведенные особенности свидетельствует о том, что на Руси в конце XV в. была сделана попытка восстановить древнюю традицию женского пострига, однако в результате получилось смешанное последование, совмещающее древнюю константинопольскую практику XIXII вв. и практику мужского пострига конца XIV в. Списки этого чина пострижения в монахини использовались нечасто, они сохранились только в некоторых требниках. Подавляющее число рукописей XV в. содержат общее для мужчин и женщин пострижение в великую схиму.

\section{2. Исторические данные о женском монашестве на Руси и на Балканах}

Чтобы понять степень востребованности и особенности распространения специального чина пострижения в монахини в славянской традиции, кажется необходимым поставить вопрос о сравнительной истории становления и развития женского монашества и женских монастырей на Руси и на Балканах. Данная часть нашей статьи посвящена реконструкции средневекового исторического контекста на основании анализа конкретных примеров: мы рассмотрим истории женщин, принявших монашеский постриг, основавших монашеские общины или возглавивших монастыри, сменивших светское имя на иноческое, живших в монастырях либо «в свету» в монашеском статусе.

Как следует из чина женского пострига, постригаемая обручается Христу как небесному жениху - именно это отличает этот чин от «стандартного» текста монашеского пострижения. Встает вопрос, насколько это гендерное отличие могло иметь значение в средневековых реалиях византийского, балканского или древнерусского ареала. С социальной точки зрения можно говорить о нескольких наиболее распространенных мотивах для принятия монашества женщинами: монашество как альтернатива браку для незамужних девушек (для знатных, желавших избежать нежеланного замужества, или для бедных, лишенных шанса на замужество из-за отсутствия приданного); принятие монашества вдовами после смерти супруга (как предпочтительная с христианской 
точки зрения альтернатива второму браку, а также как гарантия содержания вдовы монастырем). Причиной мог стать распад семьи: женщина отправлялась в монастырь, оставляя мужу шанс на новый брак (вместо или после развода, например, по причине бесплодия женщины); в некоторых случаях жен правителей насильно постригают в монахини, освобождая место для более выгодного династического союза [Garland 1999: 137]. Нередким было принятие монашества обоими супругами по обоюдному согласию, часто по причине бесплодия или на старости лет ${ }^{1}$.

Символическое обручение Христу, по идее, имеет смысл только в первом случае: если монашеский постриг принимает девушка, которая прежде не была замужем и предпочла таким образом небесного жениха земному. В других случаях, если женщина уже ранее была супругой в светской жизни, то, принимая монашество, она скорее «следует Христу», отказывается от благ земной жизни, выбирает жизнь ангельскую, как в случае с мужским постригом, однако идея обручения Христу, «повторного брака» с Христом кажется в таком случае менее логичной для Средневековья.

При обращении к средневековым источникам становится ясно, что сведения о женском монашестве в православной традиции у славян крайне скудны. Известны в основном истории о постриге жен или сестер правителей, а также о ктиторстве, когда женщины, в том числе знатные, становились основательницами монастырей и принимали постриг. Так, например, прославилась Феодора Синадена, основавшая женский монастырь Богородицы Твердое Упование в Константинополе начала XIV в. для того, чтобы вступить туда со своей дочерью Евфросинией [Delehaye 1921: 18-105; BMFD IV: 1487, 1512-1579, № 57]. Представления исследователей об особенностях женского средневекового монашества во многом опираются на источники и традиции Нового времени. Мы попытаемся проанализировать сведения, касающиеся истории женского монашества в средневековых Болгарии и Сербии, а также в Древней Руси вплоть до конца XIV в. Нашей основной задачей при этом является контекстуализация сведений о чине пострижения в свете исторических данных о женском постриге и женском монашестве.

Из ответов папы Николая I болгарскому царю Борису (866 г.) известно, что царь интересовался, является ли грехом пострижение вдов в монахини против их желания (si mulierem viduam nolentem monachicam

1 Так, например, из актов Лавры св. Афанасия на Афоне известно о бездетной паре провинциальных ктиторов Гликерии и Иоанне, живших на рубеже X-XI вв. на греческом острове Скирос, решивших на старости лет принять монашество и переделать свой дом в монастырь, завещав его в качестве метохия Лавре [Actes de Lavra I: 159; Malamut 1988: 476-477, 515; Neville 2014]. 
vitam suscipere quis monacham fecerit, peccatum comittat). В главе 87 папа четко осудил такую практику насильственного пострижения, поскольку в таком случае принуждающий к постригу совершает грех; для монахини такой постриг также не является добродетелью, ведь для нее монашеская жизнь не стала итогом ее собственного выбора [ЛИБИ 2: 116-117]. Неясно, насколько вопрос царя Бориса был продиктован социальной ситуацией в Болгарии или наличием в его собственном семействе и окружении большого количества вдов [Николова 2010: 569]. Из постановки вопроса, однако, очевидно, что такая практика насильственного пострижения вдов в Болгарии IX в. существовала и была востребована.

Один из наиболее ранних известных примеров женского пострига у южных славян - монашество княгини Косары ${ }^{2}$, дочери или родственницы болгарского царя Самуила (976-1014), супруги и вдовы князя Дукли Иоанна-Владимира [Пириватрић 1997: 105-106]. По версии Хроники попа Дуклянина, после того, как ее муж был убит в 1016 г. (с точки зрения агиографии, принял мученическую кончину), горюющая вдова князя Косара забрала останки мужа и положила его мощи в саркофаг в церкви святой Марии на острове в Скадарском озере. Сама она приняла монашество, жила святой и праведной жизнью и после смерти была погребена в той же церкви, у ног своего мужа (Uxor vero Vladimiri, Cossara, sanctimonialis effecta, pie et sancte vixit, et in eodem templo sepulta fuit ad pedes viri sui) [Monumenta montenegrina 2001: 57]. В сообщении католического епископа Скадра Конгрегации веры (1696 г.) утверждалось, что монастырь при церкви Пречистой Богородицы Краинской на Скадарском озере был основан самой Косарой (в монашестве Феодорой) [Degrand 1901: 117; Веселиновић 1909: 171]. Вероятно, Косара действительно основала церковь или монастырь на острове, иначе трудно объяснить, на каком основании ей удалось получить разрешение на установление саркофага для супруга и для себя в помещении церкви. Однако неизвестно, где вдова святого князя приняла постриг, по какому обряду, основала ли она и женскую общину при монастыре и продолжала ли жить там после принятия пострига.

Немного известно о женском монашестве в домонгольской Руси. В Киеве во второй половине XI в., по-видимому, существовало несколько женских монастырей, в том числе монастырь св. Николая на Днепре и монастырь св. Андрея. Сведения о женских монастырях содержатся в Повести временных лет, а также в Киево-Печерском патерике, в котором повествуется о матери святого Феодосия, вдове, принявшей постриг

2 В сербской историографии Косара-Феодора традиционно считается «первой сербской монахиней» [Веселиновић 1909: 171; Грујић 1932: 239]. 
в монастыре св. Николая и жившей в нем до смерти [КПП 1991: 27]. Этот монастырь, вероятно, находился под особым покровительством княгини Гертруды, поскольку Феодосий обращался к ней с просьбой пристроить его мать в монастырь. Киевский князь Всеволод считается основателем женского монастыря св. Андрея (1086)3 , в котором приняла постриг его дочь Янка. Она, по-видимому, стала первой игуменьей монастыря, собрав общину инокинь и организовав их в соответствии с «монастырским чином»:

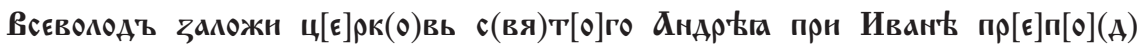
[о]Бномь мнтрополнт'Б. Пострнже(с)[є] Аџн егО А чернорнгНци многн, превываше с ннми по манастырьскому чнну [ПСРЛ 2: 137].

Если в случае с матерью Феодосия речь идет о постриге вдовы незнатного рода, поступившей в монастырь по покровительству княгини, то Янка была девушкой княжеского рода, принявшей монашество в княжеском монастыре, специально для нее основанном. В обоих случаях можно говорить о существовании женских монашеских общин, членами или предстоятельницами которых становились постригаемые. Летописец подчеркнул каноничность устройства этого женского монастыря, его соответствие монашеским правилам [Leber 2019: 264-266]. Оба монастыря были частью киевского городского пространства ${ }^{4}$.

Из жития древнерусской святой Евфросинии Полоцкой (1101/11051173), внучки полоцкого князя Всеслава, известно, что Предслава (Евфросиния) в возрасте 12 лет решила принять монашеский постриг, чтобы избежать предстоящего замужества. Агиограф представил ее решение как осознанную критику брака и семейной жизни:

КаКО Се БУАЕ(Т), WЖЕ W(Т)[Е](Ц) МОН МЫСАНТЬ ПРНПРАЧН МА МУЖЕВН. ТО аЩЕ ТАКО

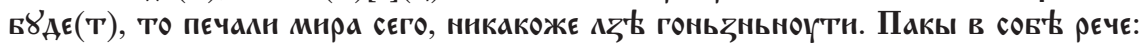

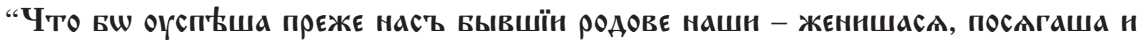
КНАЖНШа, НЪ НЕ В'ЧноваШа. ЖитїЕ пра $(X)$ и ХУжєє паогчнны [Волок.216, л. 208а] $]^{5}$.

3 По мнению Ю. А. Артамонова [2019], Андреевский монастырь в Киеве должен рассматриваться как «двойной монастырь» (по аналогии с византийской практикой двойных монастырей [Mitsiou 2014]). В историографии утверждается, что в Киеве в домонгольский период было четыре женских монастыря. Общее число женских монастырей в древнерусских городах этого периода колеблется между 12 и 17 [Емченко 2011: 179].

4 Поскольку тема пострига многочисленных супруг и вдов древнерусских князей в монахини достаточно хорошо известна в историографии [Емченко 2002; Eadem 2011; Успенские 2017: 222-225], в дальнейшем будут рассматриваться подробно только примеры пострига дев в Древней Руси.

5 Житие здесь рассматривается по списку [Волок.216, л. 206a-221a] (XVI в.). 
Такой пример не устраивает Предславу, она хочет следовать святым женам-подвижницам и мученицам, которые предпочли земному жениху жениха небесного:

व

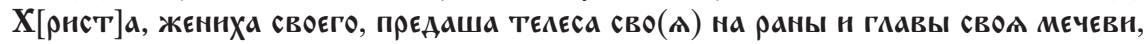

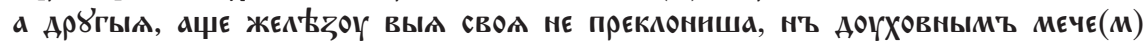

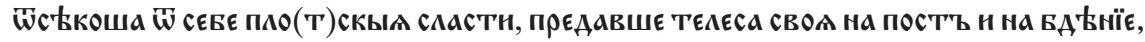

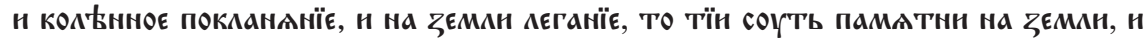

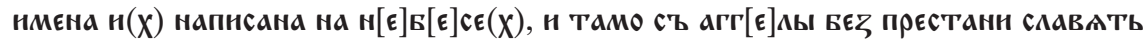
в(о)га... [Волок.216, лл. 208a-209].

В отличие от киевской княжны Янки, Предслава отправляется втайне от родителей в уже действующий женский монастырь в Полоцке, где она Хочет постричься В монаХини и бЫть по(А) иг४мєньєю КНяГИНей Романовой и повнн४ющнсл сє[с]тра(м) [л. 209]. Игуменья сперва отказывается ее постричь, возрьвшн на юность єА и опасаясь преследования со стороны князя. После того, как юная княжна ее переубедила, игуменья согласилась.

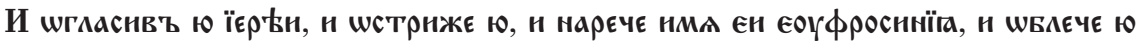

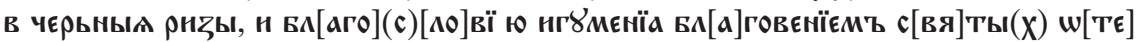
ЦЪ, Н РЕЧЕ ЕН: БОГАН, УААО, ПОСАЪ(А)СТВОГЮЮНН ПРЕЖЕ ТЕБЕ БЫВШНМЪ ЖЕНАМЪ

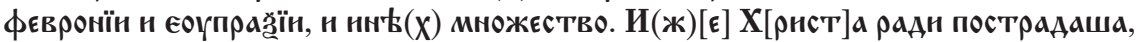

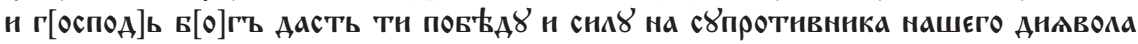
[Волок.216, л. 210].

Отец и семья княжны встретили новость с жалостью, оплакивая уход девицы в монастырь как фактическую смерть для мира земного. Ее решение вступить в монастырь до замужества выглядит исключительным по крайней мере для девушки княжеского рода. Очевидно, что Евфросиния при этом не прерывала контактов со своей семьей. Она постригла в монахини свою сестру Городиславу, вызвав гнев отца, который потерял второй шанс выгодно выдать дочь замуж. Другая богатая княжна Звенислава сначала пожертвовала солидные вклады в монастырь, а затем попросила Евфросинию о постриге. Средства Звениславы, по-видимому, вместе с вкладами из княжеской казны послужили для основания и строительства женского и мужского монастырей св. Спаса в Полоцке. В основанном ею женском монастыре Евфросиния стала игуменьей. В житии она выступает настоящим миссионером, обладающим особым даром видеть предназначение девиц и мотивирующим других девушек следовать Христу: Аанъ же Бы[сть] Ааръ ва[а]женнен єогфросннїн $\boldsymbol{W}$ в[0]

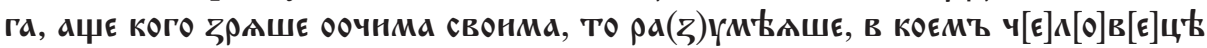

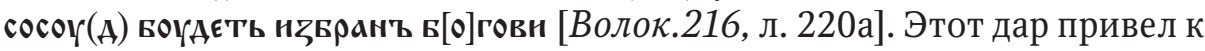


новому конфликту: она обратилась к племянницам, княжнам Кироан-

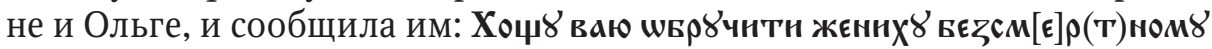
и ввєстї в чєртог' ц[а]р(c)тва єго [л. 220а]. Несмотря на сопротивление родителей, но с согласия самих девиц, местный епископ Дионисий был призван постричь княжон в монахини. Новоиспеченных монахинь Агафию и Евфимию Евфросиния вместе с основанными ею монастырями оставила на попечение своей сестры монахини Евдокии, а сама, въємши м8жєскоую крьпость, отправилась в паломничество в Иерусалим [Волок.216, л. 222; Белякова 2011: 71; Емченко 2011: 180-181].

В Сербии Неманичей первый пример женского монашеского пути показала супруга Стефана Немани (ок. 1168-1196), мать св. Саввы Анна [Грујић 1932: 239]. Известно, что постриг она приняла совместно с мужем в монастыре Студеница в 1196 г. Ее решение объясняется в разных версиях жития св. Стефана (Симеона) Немани желанием во всем следовать мужу. Если в житии Симеона Доментиан (ок. 1210-1264) пишет, что Анна последовала мужу и свєтынмь вогомювивынмь д 'вамь [Даничић 1865: 44], то в житии св. Саввы того же автора (1243) говорится, что идея Анны принять постриг была связана с желанием следовать свєтынмь вєанкынмь царнцамь, а также сыну - святителю Савве, который, последовав Христу, подал пример и своим родителям [Даничић 1865: 152]. Если сравнение с «девами» можно объяснить сходством с текстом чина женского пострига, то очевидно, что сравнение с «царицами» скорее было призвано соответствовать социальным и историческим реалиям, при которых жена и мать правителей и святителей, принимая монашество так же, как ее муж и сын, в своей монашеской роли «матери Анастасии» открывает путь монашества и святости для женщин из династии Неманичей. В сербских помянниках она упоминается как монахиня Анастасия, супруга св. Симеона. Эти два понятия - монахиня и супруга - явно не исключали друг друга в понимании современников [Leber 2018: 190]. Монастырь Топлица в Куршумлии, который, вероятно, был основан совместно обоими супругами [САНу446: 121б-122а] ${ }^{6}$, стал местом пребывания Анны-Анастасии после принятия пострига; там она, по-видимому, управляла действующей женской монашеской общиной [Ћоровић 1939: 21]

Супруга болгарского царя Ивана Асеня I (ок. 1190-1195), «новая и благочестивая царица» Елена, мать царя Ивана Асеня II (ок. 1218-

6 По мнению В. Марковича, Стефан Неманя основал первым делом женский монастырь Топлица, поскольку на тот момент существовало слишком много мужских монастырей [Марковић 1920: 45]. Однако его версия не подкреплена источниками.

7 Возможно, что дочь Стефана Немани и Анны Вука приняла монашеский постриг и имя Ефимия [Грујић 1932: 239]. 
1241), упоминается как въъємшон на сл агг[є]л[ь]скын швраъь Евгения в Бориловом Синодике [БС 2012: 165; Божилов 1994: 35]. Первая супруга Ивана Асеня II, Анна, брак с которой был признан незаконным, приняла монашеский постриг, чтобы обеспечить царю возможность союза с венгерской принцессой Анной Марией. В Бориловом Синодике она упомянута как монахиня Анисия [БС 2012: 165]. После смерти Анны Марии Венгерской в 1237 г. царь женился на дочери эпирского правителя Ирине Комниной. Овдовевшая Ирина с сыном - царем Михаилом Асенем - была изображена на ктиторском портрете на западном фасаде базилики Таксиархеос в Кастории (вероятно, за существенный вклад

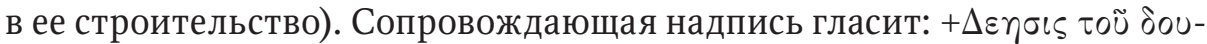
$\lambda$

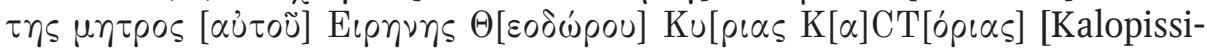
Verti 1992: 95]. На ктиторском портрете, датируемом периодом между 1246 и 1253, Ирина Комнина изображена как правительница, а не как монахиня ${ }^{8}$ Вероятно, лишь после смерти сына царя Михаила I Асеня (1256) Ирина была вынуждена принять монашеский постриг под именем Ксения. Так говорится о ней в синодике: и Ирннъ, ва(а)гочьстнвън

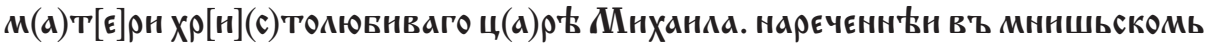
овраз' дূєнн, вЊчнаа памА(т)[ь] [БС 2012: 165; Божилов 1994: 87]. ОПять же неизвестно, в каком именно монастыре Ирина приняла монашество, жила ли она когда-либо в монастыре - или для вдовы сам факт изменения статуса на монашеский был достаточным для конкретных политических и социальных целей [Николова 2010: 564].

Древнерусская святая Евфросиния Суздальская, дочь черниговского князя Михаила Всеволодовича (ум. 1245), прославилась своей подвижнической жизнью, подробности которой известны благодаря житию, написанному существенно позже, в XV/XVI вв. [Емченко 2011: 182-183]. По его версии, княжна Феодулия отправилась в 1233 г. в Суздаль, чтобы заключить брак с князем Феодором Ярославичем, братом Александра Невского. Накануне отъезда Феодулии было видение: Богородица объявила ей, что ни «скверна мира сего, ни же сочтание обрученного ти» Феодулию не коснутся, «но Параклитом осъняема будеши и в моеи обители дњвьственыхъ лицъ жилище имьти имаши» [Клосс 2001: 382-383]. Чудесным (для не желавшей замужества невесты) образом жених скончался, не дождавшись бракосочетания, а Феодулия попросила игуменью Ризоположенского монастыря постричь ее в монахини и приняла имя Евфросиния. И здесь в обращении игуменьи к новой монахине звучит тема обручения Христу: «Рече же еи игумения:

8 О дискуссии в историографии и различной интерпретации ктиторского изображения в Кастории см.: [Leber 2018: 295-296]. 
“Христос, Ему же ты обручена, зять небесныи, Тъи тя достоину сотворит невьстника Своего” [Ibid.: 384]. Несмотря на княжеское происхождение, Евфросиния предпочла оставаться простой монахиней в монастыре, однако она выделялась своим образованием. Как и Евфросиния Полоцкая, она подавала пример монашеского пути другим женщинам, пророчествовала и т. д. С точки зрения истории монашества интерес вызывает описанная в ее житии практика отделения девушек-монахинь от монахинь с опытом брачной жизни:

Бъ же у великиа тоя игумении сицевъ чин уставися во обители: отнеле же Еуфросиниа вльзе в монастырь, дъвы избираше нескверныя во обитель Пресвятыа Богородицы, и тако проименова ю девичею обителью. А иже жены мужатицы или вдовыя, то в другую обитель посылаше и ту постризаше их [Ibid.: 390].

Для дев-монахинь Евфросиния основала отдельную церковь и помещения. При этом она запретила светским замужним женщинам вступать в контакт с монахинями-девушками, они могли общаться только с монахинями, имевшими опыт семейной жизни: «заповъда же девицам черноризицам с мужатыми женами бесьдовати, но точию с девицами. Жены же посылаше ко второи инокыням в другую обитель» [Ibid.: 390]. Можно предположить, что такое деление могло отражаться и на чине пострига, который отличался бы в случае пострига девиц от пострига жен и вдов. Очевидно, что в Суздале, как и других древнерусских городах, в женских монастырях было достаточно обеих категорий монахинь. Однако только на основании этого жития трудно сказать, насколько четко такое разделение между девами и женами практиковалось в женских монастырях середины XIII в.; возможно, оно является продуктом представлений русского епископата начала XVI в., перенесенным на более раннюю эпоху.

При этом в другом, менее известном древнерусском житии княжны Софии Ярославны Тверской [Клосс 2001: 204-206; Кучкин 2006: 110113] встречаются указания на то, что разница в статусе дев и жен среди монахинь была совершенно очевидной и служила поводом для конфликтов в основанном ею женском монастыре. В отличие от обеих святых Евфросиний, София была пострижена в 1294 г. «в манасътыри в моужскомъ святого архистратига Михаила» тверским епископом Андреем и игуменом монастыря Юрием. По-видимому, она не меняла имя при постриге, по крайней мере, в житии нет указаний на ее альтернативное «светское» имя [Успенские 2017: 85]. По мнению В. А. Кучкина, выбор места для пострига объяснялся тем, что в Твери на тот момент не существовало женского монастыря. Уже будучи монахиней, София основала 
женскую обитель св. Афанасия [Кучкин 2006: 108, 110]. Среди текстов, вдохновлявших княжну на монашеский путь, агиограф называет «Житья преждних святыхъ дьвъ Феклы, Февронии, Еоупраксии и прочих, како презрђша славоу мира сего» [Ibid.: 111]. Если имена мучениц Февронии и Евпраксии встречаются в двух других женских житиях Евфросинии Полоцкой и Евфросинии Суздальской, - то имя Феклы, спутницы апостола Петра, упомянутой в рассматриваемом выше чине женского пострига, появляется впервые. В речах к монахиням София много внимания уделяет теме девственности:

Лъпо было комоуждо насъ того боятися, понеже дъвы есмы. И паки о семъ молю вы, сестры, бога ради не оукаряите стариць, глаголющи: мы дъвы. Блюдите сего, еже глаголетъ писание: мнози от блоудниць дъъвы быша и мнози дъъьство соблюдше прокажены быша [Ibid.: 112-113].

С одной стороны, София безусловно подчеркивает важность монахинь-дев: они отдали предпочтение сохранению девственности и посвящению Христу, отказались от статуса, богатства, замужества и т. д. С другой стороны, из этой цитаты следует, что в тверском монастыре св. Афанасия жили также пожилые монахини с опытом брачной жизни (в первую очередь - вдовы [Сидоров 2002: 149]), которые явно не пользовались уважением у монахинь-дев, что вызвало реакцию Софии. И здесь возникает тот же вопрос, как и в случае с разделением монастырей и монашеского пространства в житии Евфросинии Суздальской: возможно ли, что разница в отношении к монахиням разного брачного статуса закладывалась уже на уровне чина пострижения? Также неясно, в каких случаях постриг осуществлял епископ: влияли ли на почетность обряда девственность или знатность постригаемой персоны?

В сербских и болгарских источниках конца XIII-XIV вв. известны примеры женского пострига жен и вдов правителей, а также некоторых знатных вдов, щедрых по отношению к церкви. Знаменитая сербская королева западного происхождения Елена Анжуйская приняла монашеский постриг около 1276 г., после того, как ее муж король Урош I (ок. 1243-1276), свергнутый сыном Драгутином, покинул престол и принял монашество под именем Симеон. Сербский архиепископ Данило, современник королевы, пишет в житии Елены о ее постриге очень лаконично:

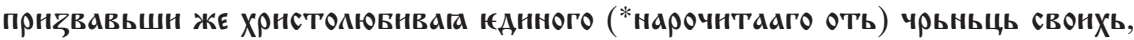

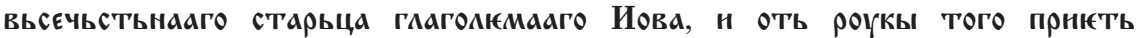

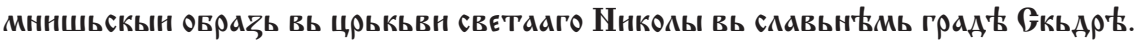

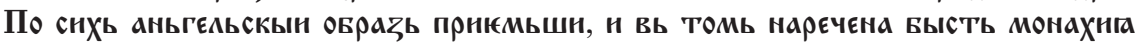
ЮАєна [Даничић 1866: 84]. 
Неизвестно, по православному или латинскому обряду Елена была пострижена в Скадаре. Архиепископ подчеркнул, что она приняла не только «монашеский образ» (малую схиму), но и «ангельский образ» - большую схиму, что соответствовало широко распространенной в средневековой Сербии практике. При этом, несмотря на обе схимы, Елена сохранила свое светское имя, тогда как, например, вдова Стефана Душана царица Елена дважды меняла имя при постриге и принятии большой схимы. Принять монашество для Елены означает, с точки зрения агиографа, пре-

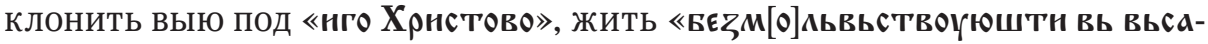

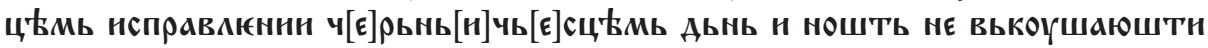
вь сласть сьна нмн покога даюштн тьлоу своюмоу» [Даничић 1866: 84]. Однако в этом описании монашеской жизни нет ни одного намека на то, что Елена была связана с каким-то конкретным монастырем или монашеской общиной. Напротив, известно, что она, приняв постриг, жила во дворце в Брняк (Косово) [Даничић 1866: 87, 88; Веселиновић 1909: 181], а православный сербский монастырь Градац, который она основала и для которого написала устав, уже будучи монахиней, был предназначен для мужчин. Очевидно, что для архиепископа, современника Елены, и для нее самой принятие монашеского пострига не означало вступления в монастырь. Похоже, что постриг Елены был частью обоюдного соглашения супругов о прекращении брака при условии, что оба принимают постриг (так же, как в случае с Анной-Анастасией и Стефаном-Симеоном Неманей). По-видимому, такая практика была достаточно распространенной в средневековой Сербии, поскольку в Законнике Стефана Душана (1349 г.) в статье 196 специально оговаривалась необходимость особого разреше-

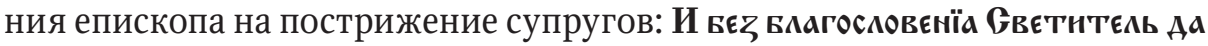
сє не пострндаю ни моүжїє ни жєне. [Радојчић 1960: 82]. ОДНако в том Же Законнике было дано указание монахиням и монахам не покидать монастырей $^{10}$, что, очевидно, не распространялось на жен и вдов правителей, в том числе вдову Душана царицу Елену.

Помимо того, что Елена Анжуйская сама никогда не жила в женском монастыре и активно поддерживала только мужские монастыри, она, по версии жития, помогала неимущим девицам, обучая их рукоделию,

9 Тот факт, что Елена сохранила светское имя, может свидетельствовать о том, что она была пострижена по латинскому обряду. Для католической средневековой традиции на Балканах перемена имени при принятии монашества не была характерной [Ostojić 1963: 54]. Еще одна сербская святая, деспотица Ангелина Бранкович, сохранила светское имя при принятии монашеского пострига [Грујић 1932: 240]. О проблеме иноческих имен и смене имен при постриге на материале древнерусских источников см.: [Успенские 2017].

10 См. статью 17 Законника Стефана Душана: W камогєрьхь: И камоугериє и

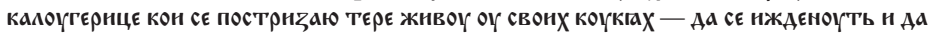
Жнвоу по МанастиреХь. [РаДојчИћ 1960: 46]. 
а также, что еще важнее, помогала им выйти замуж и обеспечивала их приданым ${ }^{11}$ [Даничић 1866: 69]. Получается, что Елена Анжуйская, в отличие от Евфросинии Полоцкой, не считала, что девицы должны постригаться в монастырь; видимо, она полагала, что христианская правительница должна способствовать их замужеству. Считала ли она, что монашеский путь был приемлем только для мужчин, пожилых женщин и вдов? Или, возможно, что женских монастырей в начале XIV в. в Cербии просто не существовало, поэтому они не могли служить реальной альтернативой замужеству? Такое предположение может объясняться и тем, что женские монастыри традиционно связаны с городским пространством, тогда как мужские монастыри в Сербии, наоборот, основывались вдалеке от городов.

Внучка Елены Анжуйской, дочь Милутина, Ана Неда, известная больше под монашеским именем Елена, получила особое признание в сербской традиции в качестве «сестры Стефана Дечанского», монахини Елены Дечанской (в первую очередь в XIX в.) [Тодић 2011: 17-20]. В этом культе она восхваляется как монахиня и «сестра» сербского святого; можно было бы предположить, что она «обручилась» Христу в раннем возрасте. Однако это не так. Ана Неда была женой болгарского правителя и матерью его троих сыновей. Хотя о ней практически отсутствуют данные в достоверных средневековых источниках, известно, что она была замужем за Михаилом Шишманом, видинским деспотом, а позднее - болгарским царем. В 1324 г. Михаил Шишман предпочел династическому союзу с сербской принцессой брак с византийской Феодорой Палеологиной. Ана Неда короткое время правила с сыном Стефаном в Болгарии, однако вскоре была свергнута и отправилась в Сербию. Считается, что она стала монахиней в Дечанах (мужском монастыре), где позже и была похоронена. Ей приписывается основание церкви в селе Крушево, монастыря Убожац и даже монастыря Будисавцы в Косово, что, впрочем, не доказано [Петковић 1950: 50]. Однако если в истории монашеского пути Аны Неды и есть что-то достоверное, то это невольное указание на отсутствие организованного женского монашества в Сербии первой половины XIV в.

Деспотица Кераца (Петрица), мать болгарского царя Ивана Александра и сербской царицы Елены, упоминается в Бориловом синодике как «принявшая ангельский образ» монахиня Феофана [БС 2012: 165-

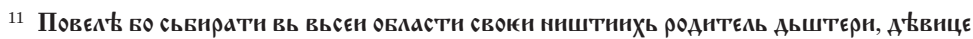

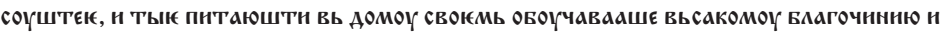

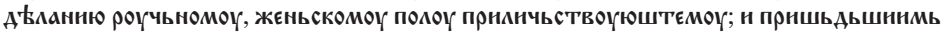
НМЬ ВЬ ВЬЗРАСТЬ ОТЬААВААШЕ НХЬ ЗА МОГЖЕ НТН ВЬ АОМЫ СВОК, ВЬСАКЫНМЬ

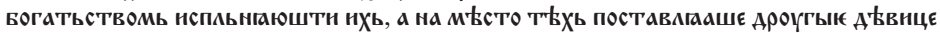
по овразоү прьвынхь. [Даничић 1866: 69, прим. 3]. По другой рукописной версии

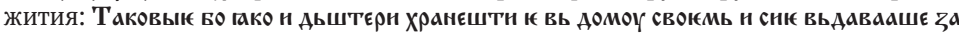
МОУЖЕ ИТН ВЬ АОМЫ СвОК вьСАКЫНМЬ БОГАТЬСТВОМЬ нспАЬНГЮШТН ИХЬ. [Ibid.: 69]. 
166]. Известно, что болгарка Кераца-Феофана состояла в переписке с римским папой Бенедиктом XII ${ }^{12}$ (как ранее сербская королева Елена Анжуйская состояла в переписке с папами Николаем IV и Бенедиктом XI [Leber 2019a: 10-11]). Этот факт стал основой для дискуссий в болгарской историографии о возможном переходе Керацы в католичество [Божилов 1994: 136-139; Георгиева 1994: 117; Николова 2010: 565-566]. Царь Иван Александр, вероятно, в принудительном порядке отправил свою первую жену Феодору (монахиню Феофану: [БС 2012: 166]) в монастырь, чтобы снова жениться. Его избранницей стала еврейка, принявшая христианство и новое имя Феодора, мать Ивана Шишмана, о которой в Бориловом синодике сказано, что она заботилась о благосостоянии церквей и основывала монастыри (Өєодwpt вл(a)

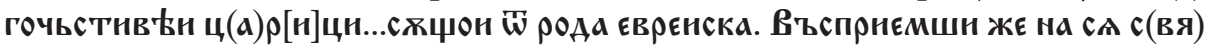

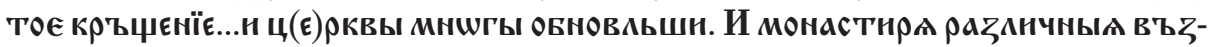
Авигшон) [БС 2012: 166]. Еще одна болгарская монахиня, упомянутая в Бориловом синодике, - Десислава (монахиня Девора), теща царя Ивана Шишмана (мать первой жены Шишмана Марии) [Ibid.: 167].

Сербская царица Елена, сестра вышеупомянутого Ивана Александра и супруга сербского царя Стефана Душана, после смерти мужа приняла монашеский постриг и имя Елизавета (в великой схиме Евгения). Как и Елена Анжуйская, она не «удалялась в монастырь», а, приняв постриг, продолжала активную политическую деятельность. Известно, что она поддерживала мужские монастыри в Македонии и на Афоне, сама основала мужской монастырь Матейче в Македонии, однако единственное свидетельство о том, что она заботилась и о женских монастырях, происходит из католического города Рагуза (Дубровник). По сведениям рагузинских хроник, во время визита Душана и Елены в Дубровник (1349) Елена одарила обитель местных кларисс: "La Regina donò alle monache de S.ta Chiara de perle, zoie, argento, et molte altre cose" [Annales Ragusini anonymi 1883: 39; Пурковић 2002: 52; Leber 2019a: 18-19].

Из Моравской Сербии известно и много других примеров знатных вдов-монахинь, в том числе княгини Милицы (монахини Евгении), вдовы князя Лазаря ${ }^{13}$, и деспотицы Елены, монахини Ефимии, вдовы деспота Углеши. Обе приняли постриг после того, как их мужья погибли в битве на Косовом поле. Милица считается основательницей

12 И. Дуйчев [1937] первым опубликовал письмо Бенедикта XII болгарской царице, где понтифик упоминает о ее крещении, а в приписке - о переходе царицы в католическую веру.

13 О сестре деспота Лазаря - Драгане - так же известно, что она после смерти супруга челника Мусы приняла монашество под именем Феодосии и основала монастырь (возможно, женский) Введения Богородицы в месте Новая Павлица (рядом с городом Брвеник) [Марковић 1920: 125; Михаиловић, Ковачевић 1989]. 
монастыря Любостыня, при котором, возможно, проживала ее подруга Елена-Ефимия, хотя Милица сама активно занималась политической и ктиторской деятельностью [Марковић 1920: 131-132]. Лишь в летописи Троноша (вероятно, XVI в.; рукопись конца XVIII в.) появляется рассказ о том, что Милица

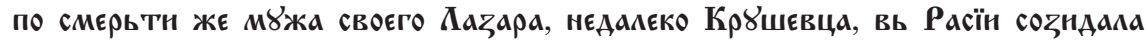

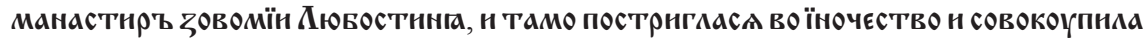

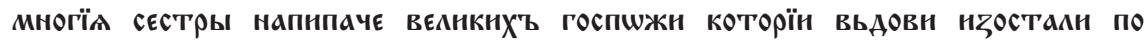

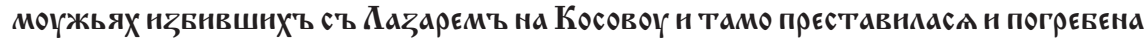
[Србский Летописац: 94].

Хотя нет оснований считать, что Милица собрала вокруг себя женскую монашескую общину, можно предположить, что, помимо Милицы и Елены, действительно были другие знатные вдовы, принявшие постриг за неимением альтернатив. С точки зрения развития культа Косовских «мучеников», также было предпочтительно представить многочисленных вдов, отправляющихся в монастырь оплакивать павших мужей. С другой стороны, очевидно, что и в этом случае женское монашество ассоциируется в Сербии только со вдовами, а исторические подробности об устройстве женских монастырей отсутствуют ${ }^{14}$. Из приведенных выше примеров видно, что похожая ситуация была характерна и для средневековой Болгарии. Принципиально отличаются сведения о монашестве девиц и развитых женских монастырях только в Древней Руси ${ }^{15}$.

\section{3. Заключение}

Среди приведенных исторических примеров наибольшее место занимают сведения о постриге жен и вдов в средневековых Болгарии и Сербии, однако практически ничего не известно о существовании организованных женских монастырей и их обитательницах. Только из древнерусских летописей и житий известно о пострижении знатных девиц (Евфросинии Полоцкой и ее родственниц, Евфросинии Суздальской, Софии Тверской).

14 Лишь начиная c XV в. можно говорить о существовании в средневековой Сербии постоянных монашеских женских общин, которые включали не только вдов и бывших супруг, но и, вероятно, девиц. По крайней мере, в этот период увеличивается количество источников, свидетельствующих о женском монашестве: в житии деспотицы Ангелины Бранкович (монахини и основательницы женского монастыря на Фрушкой горе), в грамотах о сиротах, опекаемых султаншей Марой и принимающих монашество после ее смерти, в грамотах и помянниках, свидетельствующих о донациях монахинь, на ктиторском портрете монахини Ксении, изображенной с другими монахинями в монастыре Яшунь, и т. д. См. [Пејић 2018].

15 Именно в русском языке закрепляется понятие «девичьего» (а не женского) монастыря, что также свидетельствует об устойчивой средневековой практике пострижения девиц. 
В житиях такие случаи представлены как исключительно драматические, с оплакиванием девиц, отправляющихся в монастырь. Именно проживание в городском монастыре, с наличием игуменьи и других сестер, является характерным описанием в древнерусских источниках. Это отличает их от современных им сербских и болгарских источников, которые ограничиваются указаниями на принятие пострига вдовами или бывшими супругами правителей. Здесь постриг, однако, не означает отказа от участия в светской жизни, вступления в монастырь под присмотр игуменьи или основания своей женской монашеской общины. Постриг - это скорее новый правовой статус, выгодный для бывшего супруга или сыновей вдовы. Незамужняя вдова правителя является потенциальной угрозой для ее сыновей. Вдова-монахиня, напротив, имеет шанс на активное участие в политической и церковной жизни в первую очередь в средневековой Сербии, в отдельных случаях и в Болгарии.

Рассмотренные исторические свидетельства принятия женщиной монашеского пострига на Руси и на Балканах показывают, что использование в богослужебной практике особого чина пострижения девы могло происходить только в Древней Руси, где женские монастыри устраивали в городах и где в житиях сохранились упоминания о постриге девиц как особой категории монахинь, «обручающихся Христу». При этом изученное нами древнейшее последование женского пострига в сербской рукописи Гильф.21 не имеет никаких языковых следов, которые бы свидетельствовали о влиянии на него древнерусского чинопоследования: в тексте нет русизмов, нет следов русской орфографии. Поэтому нет никаких оснований связывать этот постриг с «первым восточнославянским влиянием на южнославянскую письменность», через которое он мог бы попасть в сербские требники. В Гильф.21 содержится прямой перевод с греческого без посредства древнерусских литургических текстов. В сербской письменной традиции этот список уникален, поэтому есть все основания предполагать, что его перевод был осуществлен без какой-то конкретной цели и он, попав в сербский требник в составе других чинов пострига, в дальнейшем не применялся на практике. В Византии XI-XII вв., до захвата Константинополя крестоносцами, особая служба пострижения дев существовала: она, по-видимому, использовалась в столичных монастырях, и эта традиция могла быть перенесена на Русь. Именно в древнерусских городах возникали женские монастыри, большую роль в основании и развитии которых играли девушки из княжеского рода, выбиравшие монашеский постриг в качестве альтернативы замужеству и супружеской жизни и проповедавшие обручение небесному жениху среди знатных девиц из своего окружения. Поэтому здесь кажется наиболее вероятным существование особого типа пострижения 
для дев. Этот редкий тип монашеского пострига вряд ли имел разнообразные формы, поэтому в древнерусские монастыри, скорее всего, попало именно такое последование, как в греческом евхологии Великой церкви Coisl.213, славянский перевод которого не сохранился до наших дней. Тем не менее, список Гильф.21 показывает, что древнерусское домонгольское чинопоследование женского пострига по структуре, видимо, не имело существенных отличий от сербского списка. Возможно, в нем не было окончания чина (молитвы на снятие куколя), как в Coisl.213, однако перевод, несомненно, отличался.

\section{Сокращения}

БАН - Библиотека Российской академии наук (Научно-исследовательский отдел рукописей), С.-Петербург

ГИМ - Государственный исторический музей (Отдел рукописной и старопечатной книги), Москва

РГБ - Российская государственная библиотека (Отдел рукописей), Москва

РНБ - Российская национальная библиотека (Отдел рукописей), С.-Петербург

САНУ - Архив Српске Академије наука и уметности, Београд

$\mathrm{BnF}$ - Bibliothèque nationale de France, Paris

\section{Библиограсрия}

\section{ИСТОЧНИКИ}

РукОПИси

Арханг. 1193

Требник русский, БАН, Архангельское собр., 2-я половина XV в.

Волок. 632

Сборник житий и похвальных слов, русский, РГБ, собр. Иосифова Волоколамского монастыря (ф. 113), XVI в.

Гильф. 21

Требник сербский, РНБ, собр. А. Ф. Гильфердинга (ф.182), XIII-XIV в.

Греч. 70

Требник, греческо-славянский палимпсест, конволют; среднеболгарский фрагмент: XIIXIII в., РНБ, собрание греческих рукописей (ф. 906).

Един. 78

Требник русский, ГИМ, Единоверческое собр., 2-я половина XV в.

Олон. 34

Требник русский, РГБ, собр. Олонецкой духовной семинарии (ф. 212), 2-я половина XV в.

САНУ 446

«Горичский сборник», САНУ, 1441-1442 г.

Солов. $1085 / 1194$

Требник русский, РНБ, Библиотека Соловецкого монастыря (ф. 717), XVI в.

Солов. 1086/1195

Требник русский, РНБ, Библиотека Соловецкого монастыря (ф. 717), XVI в. 
ТСЛ. 229

Требник русский, РГБ, основное собр. Троице-Сергиевой лавры (ф. 304.I), 2-я половина XIV в.

Coisl. 213

Евхологий греческий, BnF, cod. Coislin 213, 1027 г.

Q.n.I.61

Требник сербский, РНБ, Основное собрание рукописной книги (ф. 550), 2-я половина XIV в.

\section{Издания}

БС 2012

Божилов И., Тотоманова А., Билярски И., Борилов Синодик. Издание и превод, София, 2012.

Даничић 1865

Даничић Ђ., Доментијан. Живот Светога Симеуна и Светога Саве, Биоград, 1865. 1866

Даничић Ђ., Архиепископ Данило и други. Животи краљева и архиепископа српских, Загреб, 1866.

Дуйчев 1937

Дуйчев И., Неиздадено писмо на папа Бенедикт XII до майката на царь Иван

Александра, Известия на Историческото дружество въ София, 14-15, 1937, 205-210.

КПП 1991

Киево-Печерский Патерик, или сказания о житии и подвигах святых угодников КиевоПечерской Лавры, Киев, 1991.

лиБИ 2

Латински извори за българската история, 2, София, 1960.

ПСРЛ 2

Полное собрание русских летописей, 2: Ипатьевская летопись, С.-Петербург, 1908.

РИБ 6

Русская историческая библиотека, 6, С.-Петербург, 1880.

Србский Летописац

Шафарик Я., предгов., Србский Летописац из почетка XVI-го столетия, Гласник Друштва Српске Словесности, 5, Београд, 1853, 17-112.

Actes de Lavra I

Lemerle P., ed., Actes de Lavra, 1: Des Origines à 1204, Paris, 1970.

Annales Ragusini anonymi 1883

Annales Ragusini anonymi item Nicolai de Ragnina, Zagrabiae, 1883.

BMFD 1-5

Thomas J., Constantinides Hero A., eds., Byzantine Monastic Foundation Documents, 1-5, Washington (DC), 2000.

Monumenta montenegrina 2001

Nikčević V. D., priprem., Monumenta Montenegrina, 3/1, Podgorica, 2001.

\section{Литература}

Алексеев 1999

Алексеев А. А., Текстология славянской Библии, С.-Петербург, 1999.

Артамонов 2019

Артамонов Ю. А., Двойные монастыри Древней Руси, Древняя Русъ. Bопросы медиевистики, 1 (75), 2019, 10-14. 
in Old Russia and the Balkans

Афанасьева 2019

Афанасьева Т. И., Евхологий Саввы Сербского и его рецепция в Древней Руси XIII-

XIV вв., Древняя Русъ. Вопросы медиевистики, 4 (78), 2019, 144-156.

Афанасьева et al. 2019

Афанасьева Т. И., Козак В. В., Мольков Г. А., Шарихина М. Г., Евхологий Великой церкви в славяно-русском переводе конца XIV в. Исследование и текст, Москва, С.-Петербург, 2019.

Белякова 2011

Белякова Е. В., Женщины в церковной жизни Древней Руси, Е. В. Белякова et al.,

Женщина в православии: иерковное право и российская практика, Москва, 2011, 65-92.

Божилов 1994

Божилов И., Фамилията на Асеневци (1186-1460). Генеалогия и просопография, София, 1994.

Веселиновић 1909

Веселиновић М., Српске калуђерице, Глас Српске Краљевске Академије, 80, 1909, 155-206.

Георгиева 1994

Георгиева С., Модел и действителност в аскетичния живот на жените в средновековна България, Ricerche Slavistiche, 41, 1994, 105-120.

Грујић 1932

Грујић Р. М., Промена имена при монашењу код средњевековних Срба, Гласник Скопског научног друштва, 11, 1932, 239-240.

Дмитриевский 1889

Дмитриевский А. А., Рецензия на книгу Н. Ф. Красносельцева «К истории православного богослужения. По поводу некоторых служб и обрядов, ныне не употребляющихся.

Материалы и исследования по рукописям Соловецкой библиотеки», Богословский библиографический листок, 12, 1889, 429-446.

1895

Дмитриевский А. А., Описание литургических рукописей, хранящихся в библиотеках православного Востока, 1: Тvльки́, Киев, 1895.

1901

Дмитриевский А. А., Описание литургических рукописей, хранящихся в библиотеках

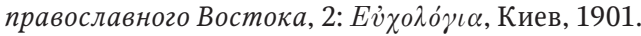

Емченко 2002

Емченко Е. Б., Женские монастыри в России, Монашество и монастыри в России XI-XX века. Исторические очерки, Москва, 2002, 245-284.

2011

Емченко Е. Б., Женские монастыри в России, Е. В. Белякова et al., Женщина в православии: церковное право и российская практика, Москва, 2011, 174-299.

Клосс 2001

Клосс Б. М., Избранные труды, 2: Очерки по истории русской агиографии XIV-XVI веков, Москва, 2001.

Красносельцев 1889

Красносельцев Н. Ф., К истории православного богослужения. По поводу некоторых церковных служб и обрядов ныне не употребляющихся (материалы и исследования по рукописям Соловецкой библиотеки), Казань, 1889.

Кучкин 2006

Кучкин В. А., Житие тверской княжны Софьи Ярославны, Проблема святых и святости в истории России. Материалы ХХ Международного семинара исторических исследований «От Рима к Третьему Риму», Москва, 2006, 96-117. 
Марковић 1920

Марковић В., Православно монаштво и манастири у средњовековној Србији, Сремски

Карловци, 1920.

Михаиловић, Ковачевић 1989

Михаиловић М., Ковачевић М., Нова Павлища, Београд, 1989.

Николова 2010

Николова Б., Монашество, манастири и манастирски живот в средновековна България,

2, София, 2010.

Пальмов 1914

Пальмов Н., Пострижение в монашество. Чины пострижения в монашество в греческой церкви. Историко-археологическое исследование, Киев, 1914.

Пејић 2018

Пејић С., Јашуњска ктиторица Ксенија с краја XV века. Оглед о женском монаштву,

Саопштења, 50, Београд, 2018, 95-110.

Пентковский 2001

Пентковский А. М., Типикон патриарха Алексия Студита в Византии и на Руси, Москва, 2001.

Петковић 1950

Петковић В., Преглед ирквених споменика кроз повеснииу српског народа, Београд, 1950.

Пириватрић 1997

Пириватрић С., Самуилова Држава. Обим и карактер, Београд, 1997.

Пурковић 2002

Пурковић М., Авињонске папе и српске земље. Светитељски култови у старој Српској држави, 2. преснимљено изд., Горњи Милановац, 2002.

Радојчић 1960

Радојчић Н., Законик иара Стефана Душана: 1349. и 1354., Београд, 1960.

Сидоров 2002

Сидоров А. И., вст. ст., пер., коммент., У истоков культуры святости. Памятники древнецерковной аскетической и монашеской письменности, Москва, 2002.

Тодић 2011

Тодић Б., Обнова сећања на Дечанску пустињу и њене подвижнике, Д. Поповић et al., Дечанска пустиња, Београд, 2011, 11-20.

Ћоровић 1939

Ћоровић В., приред, Житије Симеона Немање од Стевана Првовенчанога, Светосавски зборник, 2, Београд, 1939, 1-76.

Успенские 2017

Успенский Б. А., Успенский Ф. Б., Иноческие имена на Руси, Москва, С.-Петербург, 2017.

Щапов 1978

Щапов Я. Н., Византийское и южнославянское правовое наследие на Руси в XI-XIII в., Москва, 1978.

Degrand 1901

Degrand A., Souvenirs de la Haute-Albanie, Paris, 1901.

Delehaye 1921

Delehaye H., Deux typica byzantins de l'époque des Paléologues, Bruxelles, 1921.

Eustratiades 1935

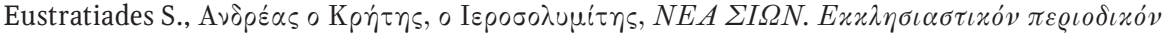

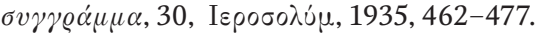

Garland 1999

Garland L., Byzantine empresses. Women and power in Byzantium AD 527-1204, New York, 1999. 


\section{Gautier 1985}

Gautier P., Le Typikon de la Théotokos Kécharitoménè, Revue des études byzantines, 34, 1985, 5-165.

Kalopissi-Verti 1992

Kalopissi-Verti S., Dedicatory Inscriptions and Donor Portraits in Thirteenth-Century Churches of Greece, Vienna, 1992.

Leber 2018

Leber T., Stifterinnen und ihre Stiftungen auf dem Balkan des Spätmittelalters - im Spannungsfeld zwischen orthodoxer und lateinischer Tradition (Inauguraldissertation zur Erlangung des Akademischen Grades eines Dr. phil., vorgelegt dem Fachbereich 07 Geschichts- und Kulturwissenschaften der Johannes Gutenberg-Universität Mainz, Mainz, 2018). 2019

Leber T., Between Veil and Tomb: Nuns and their Burial Places in Early Russia (11th-12th centuries), E. Mitsiou, E. Kountoyra Galake, eds., Women and Monasticism in the Medieval Eastern Mediterranean: Decoding a Cultural Map, Athens, 2019, 261-282. 2019a

Leber T., Female Patrons of Monasticism in the Late Medieval Balkans (13th-14th Centuries), Endowment Studies, 3, 2019, 1-35.

Malamut 1988

Malamut É., Les îles de l'Empire Byzantin VIIIe-XIIe siècles, 2, Paris, 1988.

Mitsiou 2014

Mitsiou E., Frauen als Gründerinnen von Doppelklöstern im byzantinischen Reich, L. Theis, M. Mullett et al., eds., Female Founders in Byzantium and Beyond, Vienna, Cologne, Weimar, 2014, 333-343.

Neville 2014

Neville L., The adventures of a provincial female founder: Glykeria and the rhetoric of female weakness, L. Theis, M. Mullett et al., eds., Female Founders in Byzantium and Beyond, Vienna, Cologne, Weimar, 2014, 153-162.

Ostojić 1963

Ostojić I., Benediktinci u Hrvatskoj i ostalim našim krajevima, 1, Split, 1963.

\section{References}

Afanasyeva T. I., "Euchologium of Savva Serbsky" and its reception in Northeastern Russia in the 13th-14th centuries, Old Russia. The Questions of Middle Ages, 4 (78), 2019, 144-156.

Afanasyeva T. I., Kozak V. V., Molkov G. A., Sharikhina M. G., Evkhologii Velikoi tserkvi v slaviano-russkom perevode kontsa XIV v. Issledovanie i tekst, Moscow, St. Petersburg, 2019.

Alekseev A. A., Textgeschichte der slavischen Bibel, St. Petersburg, 1999.

Artamonov Yu. A., "Double monasteries" in Old Rus', Old Russia. The Questions of Middle Ages, 1 (75), 2019, 10-14.

Belyakova E. V., Zhenshchiny v tserkovnoi zhizni Drevnei Rusi, Belyakova E. V. et al., Zhenshchina v pravoslavii: tserkovnoe pravo i rossiiskaia praktika, Moscow, 2011, 65-92.

Bozhilov I., Familiyata na Asenevtsi (1186-1460). Genealogiya i prosopografiya, 2nd ed., Sofia, 1994.

Bozhilov I., Totomanova A., Biliarski I., Borilov Sinodik. Izdanie i prevod, 2nd ed., Sofia, 2012.
Ćorović V., prired, Žitije Simeona Nemanje od Stevana Prvovenčanoga, Svetosavski zbornik, 2, Belgrade, 1939, 1-76.

Delehaye H., Deux typica byzantins de l'époque des Paléologues, Bruxelles, 1921.

Duichev I. S., Neizdadeno pismo na papa Benedikt XII do maykata na tsary Ivan Aleksandra, Bulletin de la Société historique à Sofia, 14-15, 1937, 205-210.

Emchenko E. B., Zhenskie monastyri v Rossii, E. V. Belyakova et al., Zhenshchina v pravoslavii: tserkovnoe pravo i rossiiskaia praktika, Moscow, 2011, 174-299.

Emchenko E. B., Zhenskie monastyri v Rossii, Monashestvo i monastyri v Rossii XI-XX veka. Istoricheskie ocherki, Moscow, 2002, 245-284.

Eustratiades S., Andréas o Krētēs, o Ierosolymítēs, NEA SION. Ekklēsiastikón periodikón singrámma, 30, Jerusalem, 1935, 462-477.

Garland L., Byzantine empresses. Women and power in Byzantium AD 527-1204, New York, 1999.

Gautier P., Le Typikon de la Théotokos Kécharitoménè, Revue des études byzantines, 34, 1985, 5-165. 
Georgieva S., Model i deystvitelnost v asketichniya zhivot na zhenite $\mathrm{v}$ srednovekovna Bulgariya, Ricerche Slavistiche, 41, 1994, 105-120.

Grujić R. M., Promena imena pri monašenju kod srednjevekovnih Srba, Glasnik Skopskog naučnog društva, 11, 1932, 239-240.

Kalopissi-Verti S., Dedicatory Inscriptions and Donor Portraits in Thirteenth-Century Churches of Greece, Vienna, 1992.

Kloss B. M., Izbrannye trudy, 2: Ocherki po istorii russkoi agiografii XIV-XVI vekov, Moscow, 2001.

Kuchkin V. A., Zhitie tverskoi kniazhny Sof'i Iaroslavny, Il problema dei santi e della santità nella storia della Russia: Atti del XX Seminario Internazionale di studi storici "Da Roma alla Terza Roma". Mosca, 6-7 settembre; San Pietroburgo, 11 settembre 2000, Moscow, 2006, 96-117.

Leber T., Between Veil and Tomb: Nuns and their Burial Places in Early Russia (11th-12th centuries), E. Mitsiou, E. Kountoyra Galake, eds., Women and Monasticism in the Medieval Eastern Mediterranean: Decoding a Cultural Map, Athens, 2019, 261-282.

Leber T., Female Patrons of Monasticism in the Late Medieval Balkans (13th-14th Centuries), Endowment Studies, 3, 2019, 1-35.

Malamut É., Les îles de l'Empire Byzantin VIIIeXIIe siècles, 2, Paris, 1988.

Marković V., Pravoslavno monaštvo i manastiri u srednjovekovnoj Srbiji, Sremski Karlovci, 1920.

Mihailović M., Kovačević M., Nova Pavlica, Beograd, 1989.

Mitsiou E., Frauen als Gründerinnen von Doppelklöstern im byzantinischen Reich, L. Theis, M. Mullett et al., eds., Female Founders in Byzantium and Beyond, Vienna, Cologne, Weimar, 2014, 333-343.

Neville L., The adventures of a provincial female founder: Glykeria and the rhetoric of female weakness, L. Theis, M. Mullett et al., eds., Female Founders in Byzantium and Beyond, Vienna, Cologne, Weimar, 2014, 153-162.

Nikčević V. D., priprem., Monumenta Montenegrina, 3/1, Podgorica, 2001.

Nikolova B., Monashestvo, manastiri i manastirski zhivot v srednovekovna Bulgariya, 2, Sofia, 2010.

Ostojić I., Benediktinci u Hrvatskoj i ostalim našim krajevima, 1, Split, 1963.

Pejić S., Jašunjska ktitorica Ksenija s kraja XV veka. Ogled o ženskom monaštvu, Saopštenja, 50, Beograd, 2018, 95-110.

Pentkovskiy A. M., Tipikon patriarkha Aleksiia Studita v Vizantii i na Rusi, Moscow, 2001.

Petković V., Pregled crkvenih spomenika kroz povesnicu srpskog naroda, Beograd, 1950.

Pirivatrić C., Samuilova Država. Obim i karakter, Beograd, 1997.

Purković M., Avinjonske pape i srpske zemlje. Svetiteljski kultovi u staroj Srpskoj državi, 2 presnimljeno izd., Gornji Milanovac, 2002.

Radojčić N., Zakonik cara Stefana Dušana: 1349. i 1354., Beograd, 1960.

Shchapov Ya. N., Vizantiiskoe i iuzhnoslavianskoe pravovoe nasledie na Rusi v XI-XIII v., Moscow, 1978.

Sidorov A. I., ed., $U$ istokov kul'tury sviatosti. $\mathrm{Pa}$ miatniki drevnetserkovnoi asketicheskoi i monasheskoi pis'mennosti, Moscow, 2002.

Thomas J., Constantinides Hero A., eds., Byzantine Monastic Foundation Documents, 1-5, Washington (DC), 2000.

Todić B., Obnova sećanja na Dečansku pustinju i njene podvižnike, D. Popović et al., Dečanska pustinja, Beograd, 2011, 11-20.

Uspenskij B. A., Uspenskij F. B., Inocheskie imena na Rusi, Moscow, St. Petersburg, 2017.

\section{Татьяна Игоревна Афанасьева}

доктор филологических наук

профессор кафедры русского языка филологического факультета

С.-Петербургский государственный университет

199034 С.-Петербург, Университетская наб., 11

Россия / Russia

t.i.afanasyeva@gmail.com

Таисия Дебер, Dr. des., wissenschaftliche Mitarbeiterin (post-doc)

am Lehrstuhl für Byzantinistik des Historischen Seminars

an der Johannes Gutenberg-Universität Mainz

55099 Mainz, Saarstraße 21

Deutschland / Германия

taisiya.leber@gmx.de 